\title{
Soil Phosphorus, Cattle Stocking Rates, and Water Quality in Subtropical Pastures in Florida, USA
}

\author{
John C. Capece, ${ }^{1}$ Kenneth L. Campbell, ${ }^{2}$ Patrick J. Bohlen, ${ }^{3}$ \\ Donald A. Graetz, ${ }^{4}$ and Kenneth M. Portier ${ }^{5}$

\begin{abstract}
Authors are ${ }^{1}$ Agricultural Engineer, Southern Datastream, Inc., LaBelle, FL 33935; ${ }^{2}$ Professor and Associate Chair, Agricultural and Biological Engineering Department, University of Florida, Gainesville, FL 32611; ${ }^{3}$ Director of Research, MacArthur Agro-ecology Research Center, Lake Placid, FL 33852; ${ }^{4}$ Professor, Soil and Water Science Department, University of Florida, Gainesville, FL 32611; ${ }^{5}$ Professor, Department of Statistics, University of Florida, Gainesville, FL 32611.
\end{abstract}

\begin{abstract}
Minimizing nonpoint source nutrient pollution is important to the sustainability of grazing lands. Increased nutrient loads have reduced water quality in Lake Okeechobee in south Florida, prompting establishment of a Total Maximum Daily Load (TMDL) that will require large reductions in phosphorus $(\mathrm{P})$ runoff into the lake. A significant portion of this reduction must come from beef cattle ranches, the major land use in the region. A large-scale research project, consisting of a 420-ha array of 8 improved summer and 8 semi-improved winter pastures, was established from 1998-2003 to investigate the influence of beef cattle stocking rate on nutrient loads in surface runoff. Each pasture type had two replicates of four different cattle stocking rates including a control with no cattle and stocked pastures with low, medium, and high stocking rates $\left(1.3,1.0,0.6 \mathrm{ha} \cdot \mathrm{AU}^{-1}\right.$ [animal unit] in summer pastures; 2.1, 1.6, and $0.9 \mathrm{ha} \cdot \mathrm{AU}^{-1}$ in winter pastures). Cattle stocking rate did not affect nutrient concentrations or loads in surface runoff during the study period. Average annual P discharges were $1.71 \mathrm{~kg} \cdot \mathrm{ha}^{-1} \mathrm{from}$ summer pastures and $0.25 \mathrm{~kg} \cdot \mathrm{ha}^{-1}$ from winter pastures. Average total $\mathrm{P}$ concentrations in runoff were $0.63 \mathrm{mg} \cdot \mathrm{L}^{-1}$ for summer pastures and $0.15 \mathrm{mg} \cdot \mathrm{L}^{-1}$ for winter pastures. Differences in runoff $\mathrm{P}$ were related to differences in soil $\mathrm{P}$ test results, a difference believed to be due to prior fertilization practices. Our findings show that reducing cattle stocking rates on beef cattle pastures is not an effective practice for reducing nutrient loads, and that accumulation of $\mathrm{P}$ in soil from historical fertilization has an overriding influence on P loads in surface runoff. Results indicate that reducing the overall volume of surface discharges would be a more effective strategy than altering cattle stocking practices to reduce nonpoint runoff of $P$ from cattle pastures in this region.
\end{abstract}

\section{Resumen}

Minimizar las fuentes no puntuales de contaminación de nutrientes es importante para sostenibilidad de los pastizales. El aumento de las cargas de nutrientes ha reducido la calidad del agua del Lago Okeechobee del sur de Florida, promoviendo el establecimiento de una Carga Total Máxima Diaria $(\mathrm{MDL})$ que requerirá de grandes reducciones de la descarga de fósforo $(\mathrm{P})$ en el lago. Una porción significativa de esta reducción debe venir de los ranchos con bovinos para carne, principal uso de la tierra en la región. Se estableció un proyecto a gran escala, consistente de 420 ha divididas en 8 potreros mejorados en verano y 8 potreros semimejorados en invierno. El proyecto se condujo de 1998 al 2003 para investigar la influencia de la carga animal del ganado para carne en el contenido de nutrientes del escurrimiento superficial. Cada tipo de potrero tuvo dos repeticiones de cuatro cargas animal diferentes, un control sin ganado y cargas animal baja, media, y alta $\left(1.3,1.0,0.6 \mathrm{UA} \cdot \mathrm{ha}^{-1}\right.$ en los potreros de verano y $2.1,1.6$, y $0.9 \mathrm{UA} \cdot \mathrm{ha}^{-1}$ en los de invierno). Durante el periodo de estudio, la carga animal no afectó la concentración de nutrientes o las cargas de ellos en el escurrimiento superficial. Las descargas anuales promedio de P fueron 1.71 $\mathrm{kg} \cdot \mathrm{ha}^{-1}$ de los potreros de verano y $0.25 \mathrm{~kg} \cdot \mathrm{ha}^{-1}$ de los de invierno. Las concentraciones totales promedio de $\mathrm{P}$ fueron de 0.63 $\mathrm{mg} \cdot \mathrm{L}^{-1}$ para los potreros de verano y $0.15 \mathrm{mg} \cdot \mathrm{L}^{-1}$ para las de invierno. Las diferencias de $P$ en el escurrimiento se relacionaron a diferencias en los resultados del análisis de $\mathrm{P}$ en el suelo, una diferencia que se cree es debida a prácticas de fertilización anteriores. Nuestros hallazgos muestran que reduciendo las cargas animal del ganado para carne en los potreros no es una práctica efectiva para disminuir la carga de nutrientes, y que la acumulación de $\mathrm{P}$ en el suelo proveniente de la fertilización histórica tiene influencia primordial sobre las cargas de P del escurrimiento superficial. Los resultados indican que reducir el volumen global de las descargas superficiales sería una estrategia más efectiva que alterando las prácticas de carga animal para reducir el escurrimiento no puntual de $\mathrm{P}$ de los potreros con ganado en esta región.

Key Words: nutrient loading, eutrophication, phosphorus runoff

Contribution from the Institute of Food and Agricultural Sciences, University of Florida, as part of Southern Region Project S-273 of the USDA-CSREES with support from Florida Dept of Environmental Protection, USDA-CSREES/NRICGP, Archbold Biological Station, South Florida Water Management District, Florida Dept of Agriculture and Consumer Services and the Florida Dept of Environmental Protection through the US EPA Section 319 National Monitoring Program. This is University of Florida Agricultural Experiment Station, Journal Series No. R09466 and Contribution No. 93 from the MacArthur Agro-ecology Research Center.

Correspondence: Patrick J. Bohlen, MacArthur Agro-ecology Research Center, 300 Buck Island Ranch Rd, Lake Placid, FL 33852. Email: pbohlen@archbold-station.org

Manuscript received 3 April 2005; manuscript accepted 30 July 2006. 


\section{INTRODUCTION}

The conservation and maintenance of soil and water resources is critical to the sustainability of rangelands and grazing lands (CAST 2002; Maezko et al. 2004). However, compared to other land uses little is known about nonpoint source pollution from grazing lands (Edwards et al. 2000). Grazing animals are not considered to be a major contributor to sediment and nutrient loads in surface runoff except under conditions of prolonged or heavy grazing (Thurow 1991; Brooks et al. 1997). Heavy stocking or overstocking can lead to a reduction in vegetative cover and an increase in sediment and erosion. Where cattle have access to streams they can increase nutrient pollution by depositing wastes in or near the stream or by stimulating nutrient release from sediments stirred up by cattle activity (Line et al. 1998).

Identifying and ameliorating nonpoint sources of pollution is an important aspect of maintaining water quality in regions where livestock production and grazing systems are the dominant land use. Previous studies of the effects of grazing on runoff and erosion in rangelands have shown that water quality decreases and nutrient transport increases as grazing intensity increases (Wood and Blackburn 1981; Schepers and Francis 1982). Much of the increase in nutrient runoff has been attributed to the effects of grazing on increases in sediment runoff and erosion, factors that are strongly influenced by topography, soil type, climate, and rainfall intensity (Blackburn 1984). A study of different grazing treatments in mixed grass rangeland in Montana showed minor increases in nutrient runoff with grazing, which were considered to be minimal compared to natural variability (Emmerich and Heitschmidt 2002). In small grassland watersheds under three different grazing intensities (ungrazed, heavy grazing, very heavy grazing) in Alberta, Canada, there was a modest elevation in runoff nitrate with increased grazing intensity and no consistent effects of grazing on runoff phosphorus (Mapfumo et al. 2002). The lack of consistency in observed effects of grazing intensity on nutrients in surface runoff might be due to differences in climate, vegetation, topography, or other factors, and indicates a need for more research on this topic, particularly in regions where grazing is the dominant land use and there is a mandate to reduce nonpoint sources of nutrient runoff.

Phosphorus in agricultural runoff and its contribution to eutrophication of surface water is a major environmental problem. Globally, P fertilizer use has increased net P storage in terrestrial and freshwater ecosystems by $75 \%$ over preindustrial levels, and a large portion of this increased $\mathrm{P}$ is stored in agricultural soils (Bennett et al. 2001). Long-term application of $\mathrm{P}$ fertilizers has resulted in accumulation of $\mathrm{P}$ in soils, increasing the risk of $\mathrm{P}$ transfer from soil solution to surface water (McDowell et al. 2001a, 2001b). Increases in P concentration in surface water resulting from agricultural nonpoint sources can promote eutrophication and a deterioration of surface water quality (Carpenter et al. 1998). Landuse and other factors that increase $\mathrm{P}$ storage or erosion increase the potential for P runoff into downstream ecosystems (Sharpley et al. 1994).

One region where agricultural nonpoint sources of $\mathrm{P}$ contribute to declining water quality is the Lake Okeechobee Basin, in south Florida, United States, where the dominant land use is pasture and rangeland for beef cow-calf production. Lake Okeechobee is one of the largest lakes in the United States and is a major recreational resource in the region, as well as the main water supply for the densely populated southeast coast of Florida. This lake has experienced eutrophication due, in part, to agricultural nonpoint source phosphorus runoff. Phosphorus concentrations and loads in Lake Okeechobee have doubled from $50 \mathrm{ppb}$ to $100 \mathrm{ppb}$ from the early $1970 \mathrm{~s}$ to the $1990 \mathrm{~s}$ (James et al. 1995), resulting in increased frequency of algal blooms (Havens et al. 1995), and prompting regulatory agencies to establish the first Total Maximum Daily Load (TMDL) in the state of Florida (Havens and Schelske 2001). Agricultural activities that affect water quality in Lake Okeechobee have broader significance because the lake is the main water supply for the Everglades, an imperiled wetland with significant social and environmental value (Harwell 1998). Nutrient loads into Lake Okeechobee are principally from dairy and beef cattle operations in the watershed north of the lake. In order to reduce nonpoint source nutrient pollution from these operations, there is a need to develop management practices that are science-based and economically feasible for livestock producers.

In response to these problems, the agricultural industry is mandated to achieve phosphorus load reductions, and beef cattle ranches are being targeted for a portion of these reductions. Although concentrations of $\mathrm{P}$ in surface runoff tend to be lower for cattle ranches than for other more intensive agricultural land uses, the total $\mathrm{P}$ load from beef cattle ranching is substantial due to the vast acreage of this land use (Hiscock et al. 2003). The ranching community has identified a variety of potential cattle Best Management Practices (BMPs) for water quality improvements, including modifications to fencing, drainage, feed/water location, and fertilization as well as changes in rotational grazing protocols that are expected to reduce phosphorus runoff if implemented (FCA 1999). Another management option that ranchers can manipulate is cattle stocking rate.

A research project was established at the MacArthur Agroecology Research Center, a division of Archbold Expeditions in south-central Florida, to assess the effects of cattle stocking rate on nutrient loads in surface runoff from beef cattle pastures. The objective of this integrated project was to determine the effects of cattle stocking rate on various ecological and economic factors central to the sustainable management of ranching operations in the region (Arthington et al. 2007; Swain et al. 2007; McSorley and Tanner 2007). This paper focuses on the effect of cattle stocking rate on nutrient loads and concentrations in surface runoff and phosphorus in soils of two major pasture types on beef cattle ranches in south Florida.

\section{MATERIALS AND METHODS}

\section{Site Description}

The stocking rate project was located at MacArthur Agroecology Research Center (MAERC) at the Buck Island Ranch near the town of Lake Placid, Florida. The experiment evaluated four stocking rates on improved summer pastures and semi-improved winter pastures. The selected grazing blocks 
Table 1. Design of the cattle stocking rate experiment, showing the distribution of the two replicate stocking rate treatments among the experimental pastures in the two main pasture types. One animal unit is equivalent to one cow-calf pair (USDA 2003).

\begin{tabular}{llcc}
\hline \multirow{3}{*}{ Block } & \multicolumn{3}{c}{ Treatment } \\
\cline { 2 - 4 } Summer & Description & Animal Units & Hectares/Unit \\
& Control & 0 & $\mathrm{~N} / \mathrm{A}$ \\
& Low & 15 & 1.3 \\
& Medium & 20 & 1.0 \\
\multirow{3}{*}{ Winter } & High & 35 & 0.6 \\
& Control & 0 & $\mathrm{~N} / \mathrm{A}$ \\
& Low & 15 & 2.1 \\
& Medium & 20 & 1.6 \\
& High & 35 & 0.9 \\
\hline
\end{tabular}

reflect the two principal pasture regimes typical of ranches in south Florida: improved (summer) pastures and semi-improved (winter) pastures. The summer pastures sites were planted with bahia grass (Paspalum notatum L.) and used for the grazing of cow-calf pairs during the growing season (May-October). These summer pastures were fertilized annually with $\mathrm{N}(\sim 50$ $\mathrm{kg} \cdot \mathrm{ha}^{-1}$ ) and were fertilized historically with $\mathrm{P}$ fertilizer up until 1987. The winter pastures were located on a wet prairie area containing a mixture of native grasses (Andropogon virginicus L., Axonopus affinis Chase, Panicum longifolium Torr., Paspalum spp.), along with some bahia grass, and have never been fertilized. Winter pastures were used for grazing immediately after calving and during breeding (NovemberApril). Both the winter and summer pasture blocks were located adjacent to Harney Pond Canal, a major regional conveyance linking Lake Istokpoga and Lake Okeechobee.

Soil series on the winter and summer pastures were poorly drained fine sands with a seasonally flooded hydrology. The summer pastures were primarily Felda fine sand $(89 \%)$ and the winter pastures were primarily Pineda fine sand $(70 \%)$. Felda fine sand and Pineda fine sand both are sandy or loamy, siliceous, and hyperthermic alfisols that differ only in terms of the color of the E and Bw horizon. Eighty-seven per cent of the Pineda soil in the winter pastures was overlain by a thin layer $(2.5-15 \mathrm{~cm})$ of muck, which was not as prevalent on the Felda soil in the summer pastures.

The stocking rate experiment consisted of a completely randomized design with two replications of four treatments in each of two blocks for a total of 16 plots (Table 1). The winter pastures were 32.4 ha ( 80 acres) and the summer replicates were 20.2 ha (50 acres). The greater size of the winter pastures was to accommodate the same herd size during the winter season when forage productivity was lower. The 4 stocking rate-treatments were control (0), low (15 AU [animal unit] - pasture $\left.^{-1}\right)$, medium (20 AU $\cdot$ pasture $\left.^{-1}\right)$, and high (35 $\mathrm{AU} \cdot$ pasture $\left.^{-1}\right)$. On the improved summer pastures, the nonzero treatments corresponded to $1.3,1.0$, and $0.6 \mathrm{ha} \cdot \mathrm{AU}^{-1}$, and on the winter pastures they corresponded to 2.1, 1.6, and $0.9 \mathrm{ha} \cdot \mathrm{AU}^{-1}$. Recommended stocking rates in south Florida depend upon forage species, site soil characteristics, and productivity and other factors. Four stocking densities (no cattle, low, medium, and high) were selected based on input from the
Florida Cattlemen's Association and the University of Florida to reflect typical regional stocking densities, which average 1.42 $\mathrm{ha} \cdot \mathrm{AU}^{-1}$ (Gornak and Zhang 1999). For reference, the entire 4 168-ha ranch is currently stocked at an average density of about $1.34 \mathrm{ha} \cdot \mathrm{AU}^{-1}$. In a study examining fertilizer influences on improved bahia grass pasture on nine south Florida ranches, the average stocking density was near $1.0 \mathrm{ha} \cdot \mathrm{AU}^{-1}$, which corresponds to the mid stocking rate on improved pasture in the current study (Sumner et al. 1992). More details on the experimental design, pasture characteristics (e.g. soil and vegetation), and cattle and pasture management are given in Swain et al. (2007).

\section{Surface Runoff Sampling and Analysis}

The experimental pasture plots were fenced and ditched separately from each other, with berms constructed along the fence lines between pastures so that all surface water runoff from each plot could be captured through a single trapezoidal flume and analyzed separately from runoff from other pastures. Horizontal subsurface flow between pastures was assumed to be minimal due to the low hydraulic gradient of the site and due to the fact that most surface flow in this region occurs when the groundwater is near the soil surface. All pastures had extensive drainage ditches to facilitate surface drainage during high water table conditions; the summer pastures were ditched more intensively than the winter pastures and had small lateral ditches ( $\sim 45 \mathrm{~cm}$ deep) spaced every $45 \mathrm{~m}$. Soils at the site are poorly drained fine sands with a low permeability clay layer at around $60-80 \mathrm{~cm}$ below the surface, and because surface runoff only occurs when the ground water is near the surface it is assumed that any loss of nutrients through subsurface flow is minimal relative to surface runoff.

Stilling wells, floats, and digital shaft encoders (Model SE105S, Enviro-systems, Thousand Oaks, CA), which monitored upstream and downstream water depth in each flume, served as the basis for real time calculation of flow from each pasture. Readings from the shaft encoders were recorded by data loggers (CR10X, Campbell Scientific, Logan, UT) which were programmed to pulse automatic water samplers (Model 3700, ISCO, Inc, Lincoln, NE) to collect discrete samples based on flow volume calculations and hydrograph geometry (Tremwel et al. 1996). The low relief of the pastures relative to the changing water levels in the adjacent Harney Pond Canal required that the discharge measurement and sampling system accommodated flow in both directions, including inflow from the canal as well as runoff to the canal from each individual pasture.

The water samples collected by the automated water samplers were shipped to the Harbor Branch Environmental Laboratory (Ft. Pierce, FL) in 1998; the Tennessee Valley Authority Environmental Chemistry Laboratory (Chattanooga, TN) in 1999, 2000, and 2001; and PPB Environmental Laboratories, Inc. (Gainesville, FL) in 2001, 2002, and 2003. The samples were preserved with $\mathrm{H}_{2} \mathrm{SO}_{4}$ and analyzed for total phosphorus (TP), nitrate/nitrite $\left(\mathrm{NO}_{\mathrm{x}}\right)$, ammonium $\left(\mathrm{NH}_{4}{ }^{+}\right)$, and total Kjeldahl nitrogen (TKN), using standard analytical protocols (EPA 1993). The flow volume measurements were combined with the chemistry results in a database to calculate net annual nutrient loads from each pasture plot. Thus, the 
water quality data are presented both in terms of the concentration of specific nutrients, expressed in $\mathrm{mg} \cdot \mathrm{L}^{-1}$, and the total annual load of those nutrients in surface runoff, expressed in $\mathrm{kg} \cdot \mathrm{ha}^{-1}$.

Regular grab samples were taken manually (250 total samples). Both unpreserved filtered grab samples and preserved unfiltered grab samples were taken on each sampling date just upstream from the flume. Preserved grabs were analyzed for the same parameters as samples taken by the automatic water samplers (see above), and unpreserved filtered grabs were analyzed for soluble reactive P (SRP) and nitrite $\left(\mathrm{NO}_{2}\right)$. Each time manual grab samples were collected, the dissolved oxygen (DO) content, $\mathrm{pH}$, and conductivity of surface water was measured at approximately $15 \mathrm{~cm}$ below the water surface immediately upstream of the flume.

\section{Soil Phosphorus Analysis}

Pasture soils were sampled at 10 locations per pasture to a depth of $30 \mathrm{~cm}$ in increments of $0-5,5-10,10-20$, and 20-30 $\mathrm{cm}$. Summer pastures were sampled in 1998 and 1999 and winter pastures were sampled in 1998 and 2000. Each sample was analyzed for water-soluble P (WSP) and "Soil Test" or Mehlich-1 P (double-acid-extractable P, DAP) (Mehlich 1953). Water-soluble $\mathrm{P}$ was determined on extracts with $0.01 \mathrm{M} \mathrm{CaCl}_{2}$ at a soil:solution ratio of 1:10 (Olson and Sommers 1982). For both analyses soil was air-dried at room temperature prior to extraction. Extracts were filtered and soluble P was analyzed colorimetrically using the ascorbic acid molybdate method (Olson and Sommers 1982). Data presented in this paper are averages of the two sampling dates for each pasture type.

Additional sampling was done to evaluate the spatial patterns of soil $\mathrm{P}$ distribution in pasture soils. Pasture soils were sampled in winter 2003 on a 55 -m grid pattern over the entire pastures area. At each sampling location a single $5-\mathrm{cm}$ diameter intact soil core was taken to a depth of $15 \mathrm{~cm}$ to determine the soil bulk density. This core was oven-dried at $100^{\circ} \mathrm{C}$ and weighed. Ten $2-\mathrm{cm}$ diameter cores were taken to a depth of $15 \mathrm{~cm}$ at each location and pooled into a single sample. These samples were analyzed for WSP and DAP (Mehlich-1 P) as described above, and for total P by extracting ashed samples with aqua regia solution (Allen et al. 1974). Samples were ashed in a muffle furnace for 16 hours at $450^{\circ} \mathrm{C}$ and then the ash was extracted with an aqua regia $(30 \% \mathrm{HCl}$, $50 \% \mathrm{HNO}_{3}, \mathrm{v} / \mathrm{v}$ ) solution. Filtered extracts were diluted and analyzed colorimetrically using a modified Malachite green method (D'Angelo et al. 2001).

Temporal patterns of $\mathrm{P}$ availability were evaluated using anion-exchange resin membranes (Cooperband and Logan 1994). These membranes have been shown to adsorb soluble and readily desorbable $\mathrm{P}$, including ortho-P and low molecular weight organic acids (Cooperband et al. 1999). Phosphorus sorbed to these membranes correlates strongly with bioavailable P (Abrams and Jarrell 1992). Anion exchange resin sheets (AR204-SZRA, Ionics, Watertown, MA) were cut into small strips $(2 \times 5 \mathrm{~cm})$, presaturated with $1 \mathrm{M}$ sodium acetate, and rinsed in deionized water. At 5 stratified random locations per pasture, 2 strips were placed about $20^{\circ}$ from a vertical position into slits in the soil made with a putty knife to a depth of approximately $5 \mathrm{~cm}$. The strips were left in the field for 4 days
Table 2. Total rainfall $(\mathrm{mm})$ and surface runoff $(\mathrm{mm})$ during the study period. Rainfall amounts are taken from the manual rain gauge at the main weather station at MAERC. The runoff for 1998 does not represent a complete year because the monitoring stations were not functioning until June and there were winter flow events in early 1998 due to El Nino; thus the average column does not include values from 1998.

\begin{tabular}{lcrrrrrr}
\hline Pasture Type & 1998 & 1999 & 2000 & 2001 & 2002 & 2003 & Average \\
\hline Rainfall & 1383 & 1146 & 743 & 1301 & 1559 & 1377 & 1225 \\
Summer pasture runoff & $114 \mathrm{~b}$ & 89 & 50 & 312 & 335 & $188 \mathrm{~b}$ & 186 \\
Winter pasture runoff $^{2}$ & $229 \mathrm{a}$ & 129 & 17 & 276 & 321 & $442 \mathrm{a}$ & 237 \\
Pooled SEM $^{1}$ & 36 & 26 & 13 & 47 & 42 & 52 & 38 \\
\hline
\end{tabular}

${ }^{1}$ Pooled ANOVA model standard error for the pasture type effect.

${ }^{\mathrm{ab}}$ Runoff values within a column followed by different lowercase letters are significantly different (ANOVA; $P<0.05)$.

after which time they were retrieved and returned to the laboratory and stored overnight at $4^{\circ} \mathrm{C}$. The strips were rinsed with deionized water and shaken for 1 hour in $50 \mathrm{~mL}$ centrifuge tubes with $15 \mathrm{~mL}$ of $1.0 \mathrm{~N} \mathrm{HCl}$. Extracts were filtered and soluble P analyzed colorimetrically with the ascorbic acid molybdate method (Olson and Sommers 1982).

\section{Statistical Analysis}

Differences among pasture types and stocking treatments in nutrient loads and concentrations were evaluated using analysis of variance (ANOVA) with pasture type and stocking rate as main effects. Nutrient concentration data are presented here as annual average of all samples collected within each year and loads represent the total mass of nutrients in runoff per unit area for the entire year. The flumes were not fully operational before June 1998 and some surface flow occurred during early 1998 due to wet conditions triggered by an El Niño event. Consequently the load data for 1998 represent measured loads that do not include data from the early flow events and thus do not represent full annual loads. Data from each year were analyzed separately. Soil extract data were transformed prior to analysis, if necessary, to normalize the data. Data from ionexchange resins were analyzed using a repeated-measures ANOVA and differences between summer and winter pastures were evaluated using separate ANOVAs for each sample date.

\section{RESULTS}

\section{Annual Rainfall and Surface Runoff Amounts}

Total annual runoff varied with annual rainfall but overall patterns were different for the summer and winter pastures (Table 2). Runoff represents net outflow from the pastures after subtracting any inflow that occurred during the year. Inflow in the winter pastures occurred mainly when water was pumped onto the ranch from the Harney Pond Canal during the dry season, mainly to provide water to cattle in that section of the ranch, and in the summer pastures occurred mainly during periods when the Harney Pond Canal was raised to an elevation higher than the elevation of surface water flumes in those pastures. Extreme drought conditions resulted in exceedingly low runoff amounts in 2000. In 1998 and 2003 the total runoff was significantly greater from the winter pastures than from the summer pastures but this was not the case in 2001 and 2002 
Table 3. Concentrations of total phosphorus (TP) and total Kjeldahl nitrogen (TKN) in summer and winter pasture runoff by stocking rate for 1998-2003. Values are average concentrations in $\mathrm{mg} \cdot \mathrm{L}^{-1}$ for all samples collected during the indicated calendar year.

\begin{tabular}{|c|c|c|c|c|c|c|c|c|}
\hline Block & Treatment & 1998 & 1999 & 2000 & 2001 & 2002 & 2003 & Average \\
\hline & & & - & TP mg & $\cdot L^{-1}$ & & & - \\
\hline \multirow[t]{5}{*}{ Summer } & Control & 0.56 & 0.58 & 0.45 & 0.94 & 0.82 & 0.78 & 0.69 \\
\hline & Low & 0.40 & 0.58 & 0.41 & 0.98 & 0.66 & 0.74 & 0.63 \\
\hline & Medium & 0.21 & 0.58 & 0.22 & 0.79 & 0.92 & 0.99 & 0.62 \\
\hline & High & 0.69 & 0.57 & 0.28 & 0.79 & 0.60 & 0.56 & 0.58 \\
\hline & Average & $0.47 a$ & $0.58 \mathrm{a}$ & 0.34 & $0.88 a$ & $0.75 a$ & $0.77 a$ & $0.63 a$ \\
\hline \multirow[t]{5}{*}{ Winter } & Control & 0.10 & 0.14 & 0.18 & 0.13 & 0.12 & 0.05 & 0.12 \\
\hline & Low & 0.07 & 0.11 & 0.47 & 0.15 & 0.17 & 0.11 & 0.18 \\
\hline & Medium & 0.07 & 0.15 & 0.13 & 0.11 & 0.12 & 0.09 & 0.11 \\
\hline & High & 0.08 & 0.09 & 0.34 & 0.20 & 0.18 & 0.25 & 0.19 \\
\hline & Average & $0.08 \mathrm{~b}$ & $0.12 b$ & 0.28 & $0.15 b$ & $0.15 b$ & $0.13 b$ & $0.15 b$ \\
\hline \multirow[t]{2}{*}{ Pooled SEM ${ }^{1}$} & & 0.06 & 0.04 & 0.12 & 0.05 & 0.11 & 0.1 & 0.06 \\
\hline & & & 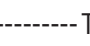 & 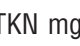 & $\cdot L^{-1}$ & 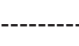 & &  \\
\hline \multirow[t]{5}{*}{ Summer } & Control & 3.43 & 4.98 & 2.76 & 3.92 & 3.16 & 3.22 & 3.58 \\
\hline & Low & 3.63 & 4.39 & 2.82 & 3.62 & 3.00 & 3.12 & 3.43 \\
\hline & Medium & 3.11 & 4.77 & 2.13 & 3.92 & 4.26 & 5.23 & 3.90 \\
\hline & High & 3.84 & 4.37 & 2.27 & 3.52 & 3.15 & 2.94 & 3.35 \\
\hline & Average & 3.50 & 4.63 & 2.50 & $3.75 a$ & 3.39 & 3.63 & 3.57 \\
\hline \multirow[t]{5}{*}{ Winter } & Control & 3.67 & 3.79 & 3.69 & 3.09 & 3.05 & 3.11 & 3.40 \\
\hline & Low & 3.50 & 6.60 & 4.46 & 2.82 & 2.85 & 3.05 & 3.88 \\
\hline & Medium & 3.51 & 3.04 & 4.27 & 2.93 & 2.58 & 2.64 & 3.16 \\
\hline & High & 3.60 & 3.68 & 4.23 & 2.80 & 2.61 & 2.81 & 3.29 \\
\hline & Average & 3.57 & 4.28 & 4.16 & $2.91 b$ & 2.77 & 2.90 & 3.43 \\
\hline Pooled SEM ${ }^{1}$ & & 0.15 & 0.86 & 0.66 & 0.17 & 0.27 & 0.44 & 0.32 \\
\hline
\end{tabular}

${ }^{1}$ Pooled model standard error for pasture type effect.

${ }^{\mathrm{ab}}$ Pasture type averages followed by different lowercase letters are significantly different $(P<0.05)$.

when runoff from the two pasture types was very similar. The reason for the differences between summer and winter runoff in the different years is not known but might have been due to regional control of canal levels, spatial variability in rainfall, or other factors.

\section{Effects of Cattle Stocking Rate}

Cattle stocking rate had no effect on concentration of total $\mathrm{P}$ (TP) or total $\mathrm{N}(\mathrm{TKN})$ in any year in either pasture type (Table 3). In $1998 \mathrm{NH}_{4}{ }^{+}$concentrations were significantly greater at the high stocking rate than at the low stocking rate $(P=0.020)$, but this is considered a random effect because the stocking rates were not applied until November 1998, and the effect was not observed in any subsequent year (Table 4). Nitrate/nitrite $\left(\mathrm{NO}_{\mathrm{x}}\right)$ concentrations were not affected by stocking rate except in 2003 when $\mathrm{NO}_{\mathrm{x}}$ concentrations tended to be greater in winter pastures at the control and low stocking rates than at the mid and high rates (Table $4, P=0.071$ ). This difference is unlikely to be related to cattle stocking because it occurred in only one year in a single pasture type. Furthermore, these differences in $\mathrm{NO}_{\mathrm{x}}$ concentration are not biologically meaningful because overall $\mathrm{NO}_{\mathrm{x}}$ concentrations were very low. There were no significant differences among stocking treatments in $\mathrm{NO}_{\mathrm{x}}$ concentrations in the summer pastures in any year. Cattle had no significant effect on nutrient loads, which are the pro-
Table 4. Concentrations of $\mathrm{NH}_{4}^{+}$and $\mathrm{NO}_{x}$ (nitrate/nitrite) concentrations in summer and winter pasture runoff by stocking rate for 19982003. Values are average concentrations in $\mathrm{mg} \cdot \mathrm{L}^{-1}$ for all samples collected during the indicated calendar year.

\begin{tabular}{|c|c|c|c|c|c|c|c|c|}
\hline Block & Treatment & 1998 & 1999 & 2000 & 2001 & 2002 & 2003 & Average \\
\hline & -- & 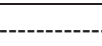 & -..- Nh & $\mathrm{H}_{4}^{+} \mathrm{r}$ & $\cdot L^{-1}$ & 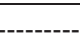 & & 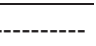 \\
\hline \multirow[t]{5}{*}{ Summer } & Control & $0.28 \mathrm{AB}$ & 0.29 & 0.31 & 0.47 & 0.25 & 0.17 & 0.28 \\
\hline & Low & $0.21 \mathrm{~B}$ & 0.26 & 0.13 & 0.36 & 0.29 & 0.15 & 0.23 \\
\hline & Medium & $0.28 \mathrm{AB}$ & 0.31 & 0.12 & 0.38 & 1.14 & 0.27 & 0.42 \\
\hline & High & $0.36 \mathrm{~A}$ & 0.56 & 0.11 & 0.42 & 0.27 & 0.14 & 0.31 \\
\hline & Average & $0.27 a$ & 0.36 & $0.17 \mathrm{~b}$ & 0.41 & 0.49 & 0.18 & 0.31 \\
\hline \multirow[t]{5}{*}{ Winter } & Control & 0.19 & 0.21 & 0.54 & 0.31 & 0.20 & 0.13 & 0.26 \\
\hline & Low & 0.17 & 0.18 & 0.78 & 0.24 & 0.19 & 0.13 & 0.28 \\
\hline & Medium & 0.19 & 0.21 & 0.89 & 0.32 & 0.18 & 0.17 & 0.33 \\
\hline & High & 0.19 & 0.22 & 1.19 & 0.23 & 0.20 & 0.18 & 0.37 \\
\hline & Average & $0.19 b$ & 0.21 & $0.85 a$ & 0.28 & 0.19 & 0.15 & 0.31 \\
\hline \multirow[t]{2}{*}{ Pooled SEM ${ }^{1}$} & & 0.02 & 0.12 & 0.28 & 0.09 & 0.23 & 0.04 & 0.09 \\
\hline & & & & $\mathrm{NO}_{x} \mathrm{mg}$ & $\cdot L^{-1}$ & & & \\
\hline \multirow[t]{5}{*}{ Summer } & Control & 0.01 & 0.02 & 0.01 & 0.07 & 0.04 & 0.01 & 0.03 \\
\hline & Low & 0.01 & 0.01 & 0.01 & 0.04 & 0.06 & 0.01 & 0.02 \\
\hline & Medium & 0.01 & 0.02 & 0.03 & 0.07 & 0.06 & 0.01 & 0.03 \\
\hline & High & 0.02 & 0.01 & 0.01 & 0.06 & 0.03 & 0.01 & 0.02 \\
\hline & Average & 0.01 & 0.02 & 0.02 & 0.06 & 0.05 & $0.01 b$ & 0.03 \\
\hline \multirow[t]{5}{*}{ Winter } & Control & 0.02 & 0.01 & 0.11 & 0.09 & 0.07 & 0.04 & 0.06 \\
\hline & Low & 0.02 & 0.05 & 0.03 & 0.18 & 0.11 & 0.04 & 0.07 \\
\hline & Medium & 0.02 & 0.03 & 0.37 & 0.21 & 0.06 & 0.02 & 0.12 \\
\hline & High & 0.04 & 0.02 & 0.10 & 0.08 & 0.05 & 0.01 & 0.05 \\
\hline & Average & 0.03 & 0.03 & 0.15 & 0.14 & 0.07 & $0.05 a$ & 0.07 \\
\hline Pooled SEM ${ }^{1}$ & & 0.00 & 0.01 & 0.05 & 0.05 & 0.02 & 0.00 & 0.02 \\
\hline
\end{tabular}

${ }^{1}$ Pooled model standard error for pasture type effect.

${ }^{a b}$ Pasture type averages followed by different lowercase letters are significantly different $(P<0.05)$.

${ }^{\mathrm{AB}}$ Stocking rate averages followed by different uppercase letters are significantly different $(P<0.05)$.

duct of nutrient concentration and total runoff volume; data are shown only for P loads but there were no effects of stocking density on loads of any $\mathrm{N}$ form either (Fig. 1).

\section{Effects of Pasture Type}

Averaged over all years, TP concentrations were 4.2-fold greater in summer pasture runoff than in winter pasture runoff (range, $0.15-0.63 \mathrm{mg} \cdot \mathrm{L}^{-1}$ ) (Table 3 ). The only year when there was no significant difference in TP concentration between the two pasture types was 2000, which was an extreme drought year with extremely low runoff amounts (Tables 1 and 3). Total annual P loads were consistently much greater in summer pasture runoff than in winter pasture runoff (Fig. 2). Excluding data from 2001, which was an extreme drought year, the average annual P loads were 7.0-fold greater from summer pastures than from winter pastures. Annual P loads, including data from the drought year, ranged from $0.06-0.51 \mathrm{~kg} \cdot \mathrm{ha}^{-1}$ in winter pastures and $0.08-3.71 \mathrm{~kg} \cdot \mathrm{ha}^{-1}$ in summer pastures.

Not only were runoff $\mathrm{P}$ concentrations greater in summer than in winter pastures, but also a significantly greater proportion of total $\mathrm{P}$ in summer pasture runoff was soluble reactive $\mathrm{P}$ (SRP), the most biologically available form (Table 5). Average total $\mathrm{P}$ concentration in manual grab samples was 4.6 -fold 

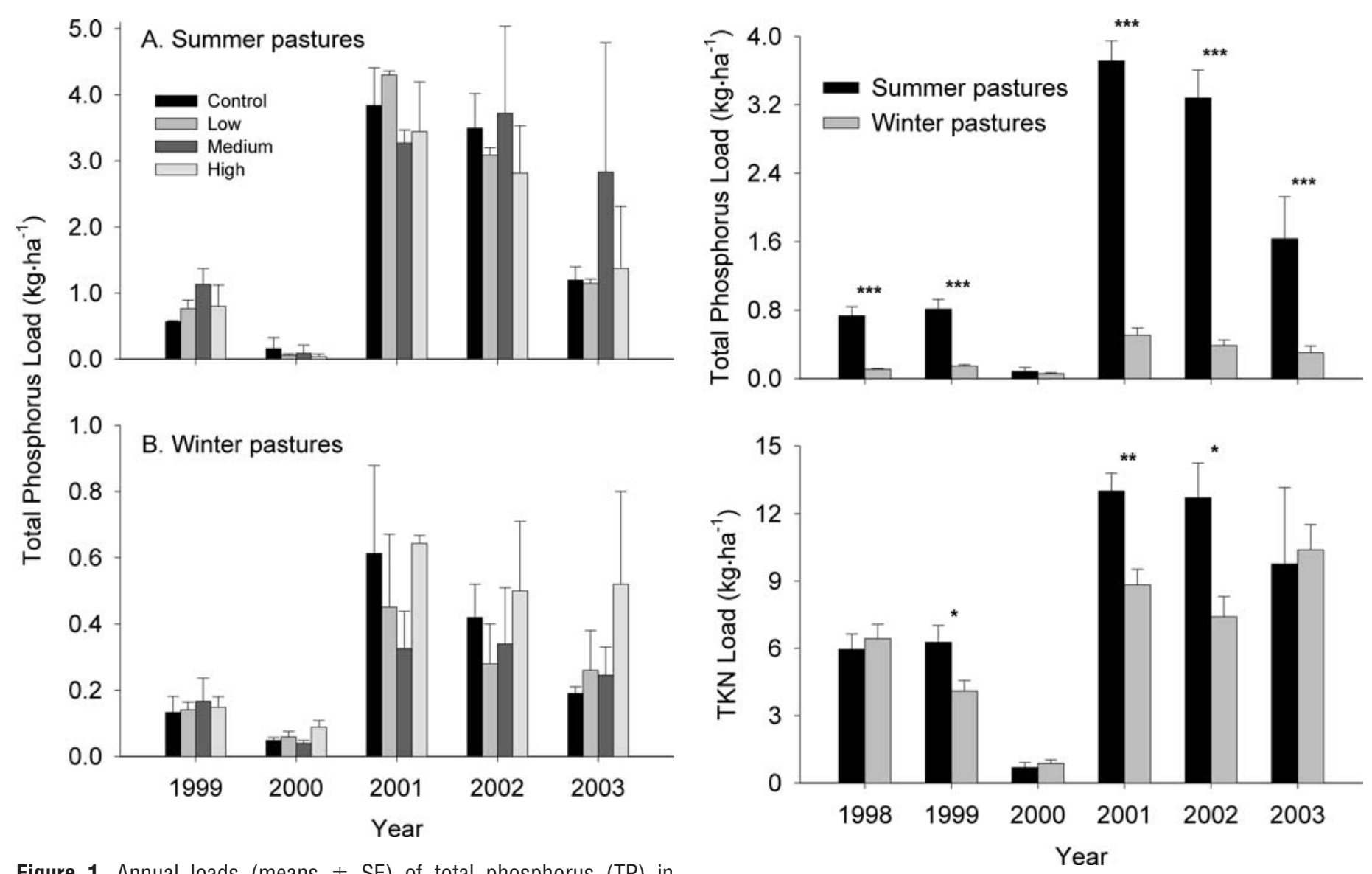

Figure 1. Annual loads (means \pm SE) of total phosphorus (TP) in surface runoff from $\mathbf{A}$, summer pastures and $\mathbf{B}$, winter pastures stocked at different cattle densities from 1999-2003. There were no significant differences in $\mathrm{P}$ loads among stocking treatments in any year in either pasture type.

greater in summer pasture runoff than in winter pasture runoff. By comparison, the average SRP concentration in grab samples was 8.8 -fold greater in summer pasture runoff than in winter pasture runoff. Accordingly, SRP was equivalent to $73 \%$ of total $\mathrm{P}$ in summer pasture runoff but only $41 \%$ of total $\mathrm{P}$ in winter pasture runoff.

Concentrations of TKN were significantly greater in summer pasture runoff than in winter pasture runoff in 2001 (Table 3). However, the total load of TKN was significantly greater in summer pasture runoff than in winter pasture runoff in 1999, 2001, and 2002 (Fig. 2). Average TKN concentrations in manual grab samples averaged 1.2-fold greater in summer pasture runoff than winter pasture runoff over the 5-year study period (Table 5).

Pasture type had significant but inconsistent effects on concentrations and loads of inorganic $\mathrm{N}$ in surface runoff. Average concentrations of $\mathrm{NH}_{4}{ }^{+}$were greater in summer than in winter pastures in 1998 and total $\mathrm{NH}_{4}{ }^{+}$loads were significantly greater in summer than winter pastures in 2001 (Table 4, Fig. 3). Nitrate/nitrite $\left(\mathrm{NO}_{\mathrm{x}}\right)$ concentrations were greater in winter than in summer pasture in 2003, and $\mathrm{NO}_{x}$ loads were greater in winter than summer pastures in 1998 and 2003 (Table 4, Fig. 3). Loads of $\mathrm{NO}_{\mathrm{x}}$ were greater in summer than in winter pastures in 2001, mainly due to inflow of water into the winter pastures during the winter drought of

Figure 2. Annual loads (means $\pm \mathrm{SE}$ ) of total phosphorus (TP) and total Kjeldahl nitrogen (TKN) in surface runoff from summer (dark bars) and winter (light bars) pastures from 1998-2003. Asterisks above pairs of bars indicate significant differences between summer and winter pastures at the $0.05\left({ }^{*}\right), 0.01\left({ }^{* *}\right)$, and $0.001\left(^{* \star *}\right)$ levels $(n=8)$.

2001, when water with relatively high $\mathrm{NO}_{\mathrm{x}}$ concentrations was pumped onto the ranch to provide water for cattle in pasture ditches. Overall $\mathrm{NO}_{\mathrm{x}}$ loads were small and negligible relative to other $\mathrm{N}$ runoff and in terms of potential biological effects.

\section{Surface Runoff Physical Parameters}

Surface runoff from summer pastures had higher $\mathrm{pH}$, higher conductivity, and lower dissolved oxygen (DO) than did runoff from the winter pastures (Table 6). The higher $\mathrm{pH}$ of the surface runoff in summer pastures was consistent with the higher $\mathrm{pH}$ in summer pasture soils (average, $4.79 \pm 0.73 \mathrm{SD}$; range 3.67-8.70) relative to winter pasture soils (average, $4.26 \pm 0.39$ SD; range, 3.25-5.53) (ANOVA; $P<0.05$ ).

\section{Phosphorus in Pasture Soils}

Results from the soil depth increment sampling in 1998-2000 showed that concentration of two readily available forms of $\mathrm{P}$ (DAP and WSP) were greatest in the surface $5 \mathrm{~cm}$ and decreased with depth, and were greater in summer than winter pastures at all depths (Table 7). The average DAP concentration in the top $5 \mathrm{~cm}$ was 2.7 -fold greater in the summer pastures than in the winter pastures and the average WSP concentration 
Table 5. Average nutrient concentrations ( $\pm \mathrm{SD}$ ) of grab samples taken from the experimental pastures during 1999-2003. Values are means of the average values for each pasture type on each sampling date $(n=33)$. TP, total phosphorus; TKN, total Kjeldahl nitrogen; $\mathrm{NO}_{\mathrm{x}}$, nitrate/ nitrite; SRP, soluble reactive phosphorus.

\begin{tabular}{lcc}
\hline & \multicolumn{2}{c}{ Pasture type } \\
\cline { 2 - 3 } Nutrient parameter & Summer pastures & Winter pastures \\
\hline & $----1---14(0.12)$ & $0.13(0.12)$ \\
$\mathrm{NH}_{4}$ & $0.03(0.01)$ & $0.02(0.01)$ \\
$\mathrm{NO}_{2}$ & $0.03(0.07)$ & $0.08(0.14)$ \\
$\mathrm{NO}_{\mathrm{x}}$ & $3.56 \mathrm{a}(1.35)$ & $2.91 \mathrm{~b}(0.84)$ \\
$\mathrm{TKN}$ & $0.69 \mathrm{a}(0.45)$ & $0.15 \mathrm{~b}(0.15)$ \\
$\mathrm{TP}$ & $0.53 \mathrm{a}(0.48)$ & $0.06 \mathrm{~b}(0.06)$ \\
SRP & $0.73 \mathrm{a}(0.29)$ & $0.41 \mathrm{~b}(0.28)$ \\
SRP/TP & &
\end{tabular}

${ }^{1}$ Ratio of SRP to total P.

${ }^{a b}$ Pasture type values within a row followed by different lowercase letters are significantly different (Kruskal-Wallis test, $P<0.05$ ).

was 3.5-fold greater in the summer pastures than in the winter pastures (Table 7). Thus, a greater portion of the soil $\mathrm{P}$ was in a soluble or readily available form in the summer pastures than in the winter pastures.
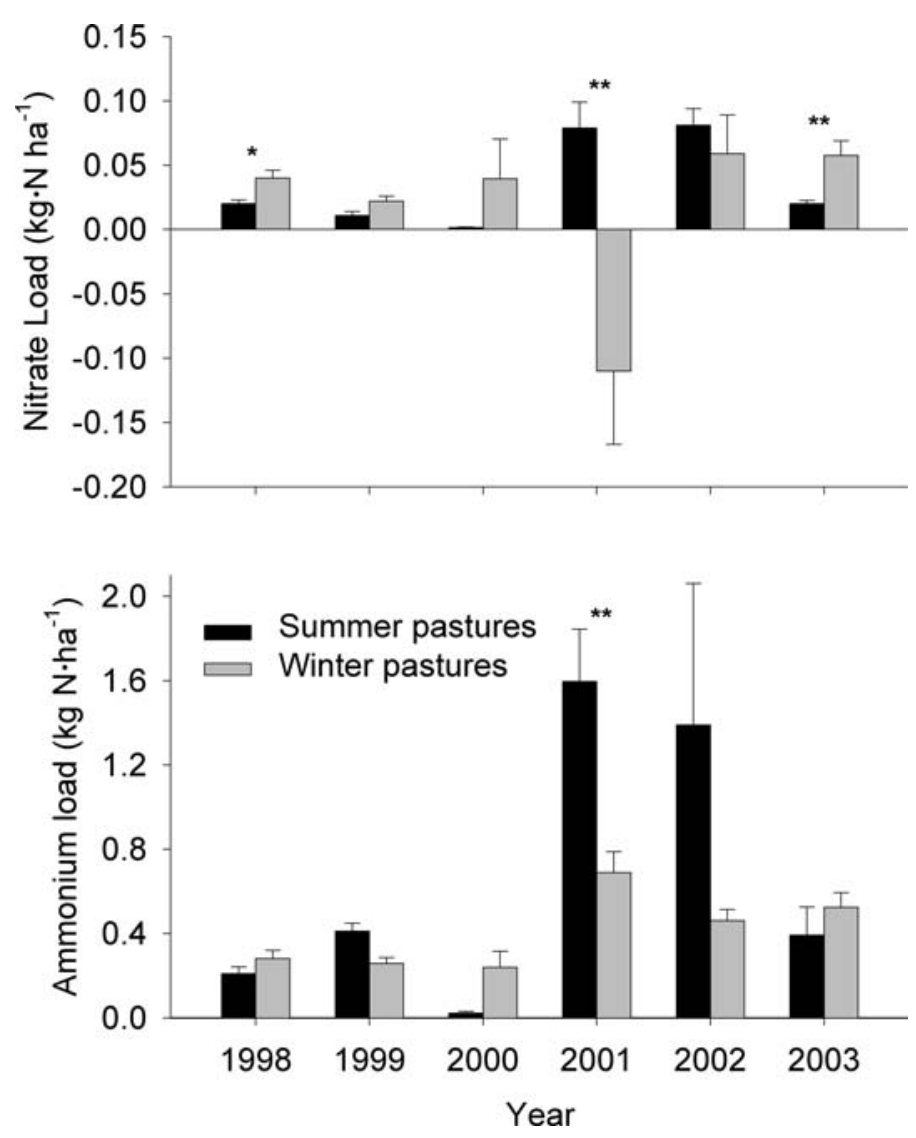

Figure 3. Annual loads (means $\pm \mathrm{SE}$ ) of nitrate/nitrite $(\mathrm{NO})$ and ammonium $\left(\mathrm{NH}_{4}{ }^{+}\right)$in surface runoff from summer and winter pastures from 1998-2003. Asterisks above pairs of bars indicate significant differences between summer and winter pastures at the $0.05\left(^{*}\right), 0.01$ $\left({ }^{* *}\right)$, and $\left.0.001{ }^{* * *}\right)$ levels $(n=8)$.
Table 6. Summary of surface runoff physical parameter data for grab samples taken during 1999-2003 from the summer and winter pastures during surface runoff events. Values are means of the average values for each pasture type on each sampling date. Values in parentheses are one standard deviation.

\begin{tabular}{lccc}
\hline & \multicolumn{3}{c}{ Pasture type } \\
\cline { 2 - 4 } Physical parameter & $\mathrm{N}_{\mathrm{s}} / \mathrm{N}_{\mathrm{w}}{ }^{1}$ & Summer & Winter \\
\hline Temp $\left({ }^{\circ} \mathrm{C}\right)$ & $32 / 38$ & $25.1(3.2)$ & $25.2(3.2)$ \\
$\mathrm{pH}$ & $32 / 38$ & $6.04 \mathrm{a}(0.63)$ & $5.35 \mathrm{~b}(1.09)$ \\
Conductivity $\left(\mu \mathrm{S} \mathrm{cm}{ }^{3}\right)$ & $33 / 37$ & $325 \mathrm{a}(99)$ & $137 \mathrm{~b}(61)$ \\
$\mathrm{D} 0(\mathrm{ppm})$ & $31 / 37$ & $1.16 \mathrm{~b}(1.19)$ & $1.87 \mathrm{a}(1.03)$ \\
\hline
\end{tabular}

${ }^{1} \mathrm{~N}_{\mathrm{S}}$ is the number of sampling occasions in the summer pasture and $\mathrm{N}_{\mathrm{w}}$ is the number of sampling occasions in the winter pastures. DO indicates dissolved oxygen.

${ }^{\mathrm{ab}}$ Means within a row followed by a different lowercase letter are significantly different $(P<0.05$, Kruskal-Wallis test)

Results from the pasture grid sampling in 2003 showed that concentrations of total soil P and DAP were, respectively, 1.4and 2.2-fold greater in summer pastures than in winter pastures, but that concentrations of WSP were actually greater in the winter pastures (Table 8). When these numbers were expressed in terms of the total content of $\mathrm{P}$ in the upper $15 \mathrm{~cm}$ of soil, taking into consideration differences between pastures in soil bulk density, the total P and DAP content were 1.6- and 2.4-fold greater, respectively, in the summer than in the winter pastures (Table 8).

Phosphorus concentrations on ion-exchange membranes (AEM-P) were greater in summer than in winter pastures throughout the study period (Repeated-measures ANOVA; $P=0.0001$ ), except on 22 July (Fig. 4). On that sample date pasture soils were very dry, which likely limited diffusion of $\mathrm{P}$ to the membrane surface, and AEM-P was greater in winter pastures where soil moisture was greater than in summer pastures. When soil conditions were wet (3 May, 8 September and 14 October) AEM-P was 5- to 10-fold greater in summer pastures than in winter pastures.

\section{DISCUSSION}

\section{Cattle Stocking Rate Effects}

The initial assumption motivating the design of this project was that cattle would increase nutrient loads in runoff and that

Table 7. Phosphorus concentration in Mehlich-1 and water-soluble extracts of soil at 4 different depths $(\mathrm{cm})$ in summer and winter pastures. Values are means $( \pm \mathrm{SE})$ for two different sampling periods for each pasture type. All values for summer and winter pastures at each soil depth are significantly different $(P<0.01)$.

\begin{tabular}{|c|c|c|c|c|}
\hline \multirow[b]{2}{*}{ Soil Depth } & \multicolumn{2}{|c|}{ Mehlich-1 P (DAP) } & \multicolumn{2}{|c|}{ Water-soluble P (WSP) } \\
\hline & Summer pasture & Winter pasture & Summer pasture & Winter pasture \\
\hline & ----------- & ------- m & $g^{-1}-$ & \\
\hline $0-5$ & $40.1 \mathrm{a}(6.6)$ & 14.5a (1.4) & $35.1 \mathrm{a}(2.5)$ & 10.0a (2.5) \\
\hline $5-10$ & $13.7 b(1.5)$ & $7.1 b(0.7)$ & $5.8 b(0.5)$ & $3.3 b(0.7)$ \\
\hline $10-20$ & $8.5 b(1.0)$ & $2.7 c(0.4)$ & $1.5 b c(0.1)$ & $0.9 b(0.1)$ \\
\hline $20-30$ & $6.8 \mathrm{~b}(1.1)$ & $0.8 \mathrm{c}(0.1)$ & $0.8 \mathrm{c}(0.1)$ & $0.4 b(0.0)$ \\
\hline
\end{tabular}

${ }^{a b}$ Values within a column followed by a different lowercase letter are significantly different $(P<0.05)$. 
Table 8. Concentrations of organic matter (OM), total soil $P$, Mehlich-1 $P(D A P)$, and water soluble $P(W S P)$ in the upper $15 \mathrm{~cm}$ of pasture soil as determined from sampling the entire pasture area on a $55-\mathrm{m}$ grid pattern. Values are means of pasture averages $(n=8)$.

\begin{tabular}{|c|c|c|c|c|}
\hline Pasture type & $\mathrm{OM}(\%)$ & Total P & $\mathrm{DAP}^{1}$ & WSP \\
\hline & \multicolumn{4}{|c|}{ 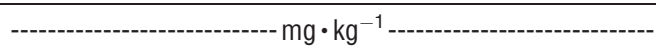 } \\
\hline Summer & 9.80 & $167.06 a$ & $10.48 \mathrm{a}$ & $2.96 \mathrm{~b}$ \\
\hline Winter & 12.85 & $119.23 b$ & $4.76 \mathrm{~b}$ & $4.73 a$ \\
\hline SEM $^{2}$ & 0.59 & 11.88 & 1.20 & 0.51 \\
\hline Summer & - & $25.97 a$ & $1.91 \mathrm{a}$ & 0.56 \\
\hline Winter & - & $15.12 b$ & $0.78 \mathrm{~b}$ & 0.79 \\
\hline SEM & - & 1.52 & 0.20 & 0.10 \\
\hline
\end{tabular}

${ }^{1}$ Mehlich-1 or double-acid-extractable $P$.

${ }^{2}$ Standard error of the mean for a one-way ANOVA.

${ }^{a b}$ Values within a column followed by different lowercase letters indicate significant differences between pasture types $(P<0.05)$.

adjustments to stocking rate could be an effective Best Management Practice (BMP) for reducing nonpoint source pollution from cattle ranches. Our results do not support that initial hypothesis but, to the contrary, show that under typical stocking rates in seasonally wet subtropical pastures in Florida cattle had no consistent effect on any nutrient parameter measured. Surface runoff from pastures with no cattle or with high stocking rates did not differ in nutrient concentrations or loads over the 5-year study period. Our findings are consistent with a small watershed scale study of fescue grassland in Alberta, Canada, where differences in grazing intensity were not shown to have a significant effect on nutrient contamination of adjacent streams (Mapfumo et al. 2002). In cases where grazing cattle have been linked to increased nutrient runoff either stocking rates were much higher than are typically encountered for beef cattle on range (e.g., Mundy et al. 2003), or the increases were due to increases in sediment loss and erosion (e.g., Schepers and Francis 1982). Our results suggest that cattle do not significantly affect nutrients in surface runoff at typical stocking rates on bahia grass pastures in south Florida.

Cattle transform nutrients from less available forms in vegetation to more labile forms in dung and urine suggesting a possible mechanism whereby they might increase nutrient runoff. Leaching of nutrients from these waste products during heavy rains or direct waste deposition in drainage ditches seemed to be plausible routes by which cattle might increase nutrient runoff. Cattle can also stimulate nutrient release into surface water by resuspending nutrient-laden sediments as they walk or loaf in ditches and wetlands (Line et al. 2000). Despite these potential routes for increased runoff due to cattle activity our results show that they did not have a significant cumulative effect on nutrients in runoff at the whole pasture scale during a 5 -year treatment period.

There are several possible explanations for why stocking rate did not affect nutrient runoff in this experiment. Forage productivity in these pastures is high (3 500-4 $500 \mathrm{~kg} \cdot \mathrm{ha}^{-1}$ peak standing biomass) and even in the high stocking rate treatment overall forage utilization in the summer pastures averaged only about $30 \%$ during the growing season (Arthington et al. 2007). This relatively low utilization is not unusual



Figure 4. Resin $P$ (means \pm S.E.) extracted from ion-exchange resin membranes placed in the field for 4 days on 8 different occasions from March 1999 to March $2000(n=8)$. Asterisks $\left({ }^{*},{ }^{* *},{ }^{* * *}\right)$ indicate a significant difference between summer and winter pastures on a particular date at the $P<0.05, P<0.01$ and $P<0.001$ level, respectively (ANOVA).

for south Florida cow-calf operations where overall ranch stocking rates are constrained by forage availability in the dry season, leading to underutilization of forage at peak biomass production in the wet season. Thus good soil cover is maintained across the pasture area, which avoids the problem of denudation and increased erosion observed in more intensive grazing systems (McDowell et al. 2003). Under the cattle management system used in the experimental pastures, the only nutrient inputs brought into the system are in $\mathrm{N}$ fertilizer applied at a moderate rate $\left(52 \mathrm{~kg} \cdot \mathrm{ha}^{-1}\right)$, and mineral and winter supplemental feed; otherwise, cattle only recycle the nutrients within the system. Although cattle waste products can increase nutrient availability at specific locations or hotspots, it is likely that these nutrients are taken up by the vegetation or soil microbial community. It is possible that these nutrients could be transported offsite during wet periods when the soil is saturated, or when waste products are deposited directly in waterways (Nash et al. 2000), but such transport did not have a measurable effect on nutrient loads in our study. Cattle can also increase nutrient runoff by increasing erosion and sediment transport, but this effect was minimal in the current study because overall slopes at the sites were less than $0.1 \%$ and velocities of surface runoff in drainage ditches were low, in the range of $0.5-1$ feet $\cdot$ second $^{-1}$ at peak flow.

Other studies have demonstrated large reductions in nutrient loads when cattle were excluded from waterways. For example exclusion of pastured dairy cows from streams in North Carolina resulted in a $76 \%$ reduction in weekly $\mathrm{P}$ loads from the pastures (Line et al. 2000). In our study cattle had free access to the main drainage ditches and were often observed spending time in these ditches during the wet season in the improved summer pastures, but this activity did not increase nutrient loads in surface runoff from the pastures. The effect of cattle in ditches on water quality in our systems might have been minimized by the flat topography of the pastures (less than $0.1 \%$ slope), which contributed to slow velocities of sur- 
face runoff as discussed above. Furthermore, our stocking rates were much lower than the rates reported from the previously cited study in which cattle were excluded from streams.

Under current management practices, there was actually a net export of $\mathrm{P}$ in cattle from the experimental pastures. When the summer and winter pastures were considered together as a whole ranch unit, more $\mathrm{P}$ was exported in calves than was imported in mineral and winter supplemental feed, and the net $\mathrm{P}$ export was greatest for the high stocking rate (Swain et al. 2007). Thus the cattle operation was actually a net exporter of $\mathrm{P}$, the main nutrient of concern from a water quality perspective, and the cattle themselves at typical stocking rates did not appear to contribute to increases in nonpoint source nutrient runoff.

It is possible that nutrient deposition can become skewed toward particular areas relative to shade, watering, or feed structures where cattle spend a disproportionate amount of time and nutrients can build up in the soil near these structures (West et al. 1989; Franzluebbers et al. 2000). If these areas are close to waterways or routes of surface runoff they could have the potential to contribute to increased nutrient loads. We did not observe that effect during the course of this experiment, but data collected from the pastures and other sites on the same ranch in the winter of 2004 show that shade and feed structures are associated with increased concentration of available $P$ in the soil around the structures (Kokemor 2004). Whether such sites would eventually lead to increased amounts of $\mathrm{P}$ in surface runoff is unknown but there was no evidence that they contributed to increased nutrient concentrations or loads in surface runoff from these pastures during the 5-year study period.

\section{Pasture Type Effects}

The most likely reason for the greater P loads in surface runoff from summer pastures compared to winter pastures is the difference in historical fertilizer use between these two pasture types. Nutrients in surface runoff are derived mainly from soils and sediments and soil $\mathrm{P}$ concentrations were substantially greater in the summer than in the winter pastures. The summer pastures have a long history of regular fertilizer application, whereas the winter pastures have never been fertilized, according to available information, which included interviews with the ranch manager who managed the ranch from 1968-1993 (D. Childs, personal communication, January 2000). Although winter pastures might never have received any $\mathrm{P}$ fertilizer, they do receive $\mathrm{P}$ inputs in the form of feed supplements and mineral, which could lead to minor $\mathrm{P}$ accumulation over time (Swain et al. 2007). We do not have specific records on the amounts of fertilizer added to the summer pastures in the past, but several lines of evidence indicate that they were regularly fertilized with P fertilizer for at least 20-30 years up until 1987. The previous ranch manager (D. Childs) and the son of the previous owner (D. Durrance, owner pre-1968, personal communication, March 2004) both indicated that the area used for the summer pasture array was regularly fertilized with $\mathrm{P}$ prior to 1987. Available records showing pre-1987 fertilizer rates for specific pastures at Buck Island Ranch indicate that the recommended rate of $\mathrm{P}$ fertilizer application was 40 pounds of $\mathrm{P}_{2} \mathrm{O}_{5}$ or about $20 \mathrm{~kg} \mathrm{P} \cdot \mathrm{ha}^{-1}$ for improved pastures. In $1987 \mathrm{P}$ fertilizer use was discontinued due to new recommendations from the University of Florida that P fertilizer use on bahia grass pastures was not necessary (Kidder et al. 2002).

In addition to the evidence provided above on fertilizer history we have other ancillary data from these sites to support our conclusion that past fertilizer use is responsible for the differences in soil and surface runoff $\mathrm{P}$ concentrations in the summer and winter pastures. Samples of surface runoff and soil water were collected from the summer and winter pastures and were analyzed for their uranium content and uranium isotope ratios to trace potential $P$ fertilizer sources. This approach takes advantage of the fact that background levels of uranium (U) in soils of south Florida are low and that the ${ }^{234} \mathrm{U} /{ }^{238} \mathrm{U}$ isotopic ratio of naturally occurring $U$ is very different from the ratio in P fertilizer and imported feed (Zielinski et al. 2000). The results showed that $U$ concentrations were significantly higher in summer pasture soils than in winter pasture soils throughout the upper $30 \mathrm{~cm}$ of the soil profile and that the ${ }^{234} \mathrm{U} /{ }^{238} \mathrm{U}$ activity ratio of $U$ in summer pasture soils indicated that it came from a P fertilizer source (Zeilinski et al. 2006). The ${ }^{234} \mathrm{U} /{ }^{238} \mathrm{U}$ activity ratio of surface runoff indicated that the majority of $U$ in surface runoff from the summer pastures was derived from a P fertilizer source. Taken together, the verbally documented history of past fertilizer use, the differences in soil chemistry between pasture types, and evidence from $U$ isotope analysis point strongly to past fertilizer use as the source of increased soil and surface runoff $\mathrm{P}$ in the summer pastures relative to the winter pastures.

A variety of factors control $P$ release from soils to surface runoff and there is often a strong relationship between soil-test $\mathrm{P}$ and runoff $\mathrm{P}$, although the relationship varies for different soils (Sharpley et al. 1995; McDowell et al. 2001a, 2001b; Torbert et al. 2002). In the nearly level, poorly drained sandy soil of the experimental pastures, surface runoff generally occurs when the groundwater reaches near the soil surface. During the period of alternating flooding and drying of surface soils that occurs in the rainy season, the surface horizon is exposed to alternating oxidative states that might cause a release of sorbed and organic P into soil solution where it could become susceptible to transport under wet conditions (Reddy and Patrick 1974; Villapando and Graetz 2001). Phosphorus concentrations in surface and interflow waters in the surface soil were higher than in deeper soil layers in a grazed grassland in southwest England (Haygarth et al. 1998) and it is likely that the surface soil layer at our sites, which had the highest concentrations of P (Hill 2003), contributed significant amounts of $\mathrm{P}$ to surface runoff. In the winter pastures these processes do not contribute to excessive $\mathrm{P}$ loads in surface runoff because the soil has relatively low $\mathrm{P}$ concentrations and is capable of retaining inorganic $\mathrm{P}$; in the summer pastures where the soil is more saturated with $\mathrm{P}$, excessive amounts of $\mathrm{P}$ are lost in surface runoff during the rainy season.

Analysis of different $\mathrm{P}$ forms in the soil in the experimental pastures revealed that nearly $60 \%$ of soil P in the upper $28 \mathrm{~cm}$ of soil was in the organic form, reflecting the low sorption capacity of these sandy soils and the potential for $\mathrm{P}$ release during flooding-drying cycles (Hill 2003; Sperry 2004). It is likely that this reservoir of organic $\mathrm{P}$ serves as a significant source of $\mathrm{P}$ that is released into soil solution during flooding and drying cycles and that becomes susceptible to transport in runoff during flooded periods. Flooding of similar soils from 
central and south Florida under controlled conditions caused a 4- to 8-fold increase in P released into effluent (Reddy 1983). In that study, soluble reactive P (SRP) accounted for $75-80 \%$ of total effluent $\mathrm{P}$, which is very similar to the proportion of SRP recorded in the runoff from summer pastures in our study (73\%; Table 5). Thus, available evidence suggests a strong tendency for high P release from soils in this region when they are exposed to flooded conditions, which occur regularly in the wet season (June-October), and that enrichment of these soils with fertilizer $\mathrm{P}$ increases the potential for $\mathrm{P}$ runoff and the proportion of readily available $\mathrm{P}$ in the runoff.

The release of $\mathrm{P}$ from pasture soils during flooding is illustrated by the temporal patterns of soil $\mathrm{P}$ availability assessed by ion-exchange membranes (Fig. 4). The difference between pasture types in AEM-P during wet periods was comparable to differences in concentrations and loads of total $\mathrm{P}$ in surface runoff from the pastures (Table 3, Fig. 2), and indicates that a much greater amount of available $\mathrm{P}$ is released into soil solution from summer pasture soils than from winter pasture soils when the soils are saturated during periods of surface runoff. The amount of $\mathrm{P}$ released apparently exceeds the capacity for uptake by plants and soil microorganisms under flooded conditions, and a significant amount of soluble $\mathrm{P}$ is apparently transported to drainage ditches and lost in surface runoff.

The differences in surface runoff physical parameters in summer and winter pastures reflects differences in pasture soils and management. The higher $\mathrm{pH}$ of summer pasture runoff was likely due to intermittent applications of lime to the summer pastures over the past 30 years at a rate of 1.1 to $3.4 \mathrm{Mg} \cdot \mathrm{ha}^{-1}$. Higher conductivity in runoff from the summer pastures indicates a higher concentration of dissolved solids than in runoff from the winter pastures that could be related to the higher nutrient concentrations in the summer pasture runoff, differences in vegetation, soil type, or elevation between the two pasture arrays. The lower dissolved oxygen levels in the runoff from the summer pastures suggest greater heterotrophic activity, possibly stimulated by the higher nutrient content of summer pasture runoff.

The degree of phosphorus saturation (DPS) in the upper 5 $\mathrm{cm}$ of soil was $20 \%$ in summer pastures and $10 \%$ in winter pastures. The DPS provides a metric to assess a threshold beyond which P is likely to be lost to soil solution and a DPS of $25 \%$ has been defined as such a threshold for some soils (Breeuwsma et al. 1995). However, this critical threshold value might vary among different soils (Beauchemin et al. 1996) and might have been exceeded at a DPS of $20 \%$ in the summer pastures in our experiment. In soils under more intensive dairy operations in the Lake Okeechobee watershed the sorption capacity of the A horizon in fine sandy Spodosols was reduced to almost zero, causing an increase in $\mathrm{P}$ concentration equilibrated with lower soil horizons (Nair et al. 1998). A similar process might be operating in soil of the improved beef cattle pastures used in the current experiment, except that more $\mathrm{P}$ would be lost to surface runoff than to deeper soil horizons due to the more poorly drained status of these soils relative to the dairy soils examined in study cited above.

An estimated $70 \%$ of the $\mathrm{P}$ imported into the Okeechobee watershed is stored in upland soils (Reddy et al. 1996; Hiscock et al. 2003). Although these soils could still have up to $75 \%$ of their P storage capacity remaining, our data suggest that they are already a significant nonpoint source of $\mathrm{P}$, despite their remaining storage capacity. Consequently, net $\mathrm{P}$ imports into the Okeechobee watershed will need to be decreased if there is any hope of achieving mandated water quality goals in the long term.

\section{MANAGEMENT IMPLICATIONS}

The results of the stocking rate experiment indicate that approaches focused on decreasing phosphorus inputs and decreasing movement of accumulated soil phosphorus into surface runoff would be more effective than approaches focused on cattle management for reducing $\mathrm{P}$ loads in surface runoff from cattle pastures. Stocking rate had no measurable effect on nutrients in surface runoff during 5 years of stocking treatments. The low replication of our stocking treatments might not have been adequate for documenting small differences between treatments, especially given the variability in nutrient load data. Even so, the lack of detectable differences in nutrient loads between stocked pastures and control pastures over a 5-year period provides little evidence that reducing stocking density within the range examined would be an effective BMP for reducing nutrient runoff from pastures in this region.

Our results suggest that elevated nutrient loads were related to historic use of $\mathrm{P}$ fertilizer. Nutrient loads and concentrations from summer pastures that were previously fertilized with $\mathrm{P}$ were 5 to 7 times greater than from winter pastures that had never been fertilized. Efforts to reduce P loads from pastures with a history of $\mathrm{P}$ fertilizer use might require remedial action targeted toward reducing leaching and runoff of accumulated soil P. Any proposed remedial action will need to consider the cost of such action and be economically feasible for ranchers.

Regulatory and legislative actions to reduce P loads from cattle ranches in the Okeechobee basin and other regions with similar problems need to establish reasonable timeframes and cost effective measures for dealing with the legacy of $\mathrm{P}$ already accumulated in upland soils. In our study, high concentrations of $\mathrm{P}$ in surface runoff from summer pastures persisted through 2003 despite the fact that $\mathrm{P}$ fertilizer use was discontinued in 1987. Net P imports to improved pastures in the Lake Okeechobee watershed declined from the late 1980s to the late 1990s but still account for $32 \%$ of total net imports to the Lake Okeechobee watershed (Hiscock et al. 2003). Furthermore, the P assimilative capacity of wetlands in the region has apparently declined over the past decade, increasing the need to reduce net $\mathrm{P}$ inputs to the watershed. Our results suggest that legacy of fertilizer $P$ can last for many years after $P$ fertilizer use is discontinued. Correspondingly, BMP programs to improve water quality should target those cattle pastures where soil $\mathrm{P}$ concentrations and surface hydrology are conducive to high $\mathrm{P}$ runoff. Reducing phosphorus runoff, either by adding amendments to bind soil phosphorus, managing water to reduce total runoff, or capturing runoff phosphorus in wetlands or other edge of farm treatment practices are among the possible approaches for reducing the movement of accumulated phosphorus into surface runoff.

\section{ACKNOWLEDGMENTS}

Thanks to our research assistants, D. Buchanan, M. Ferree, S. Harris, G. Huey, D. Ingall, E. Rawlinson, J. Rodriguez, L. Rojas, for collecting and 
processing water quality samples and maintaining field instrumentation; T. Dickson, D. Lucas, M. McMillian, S. Gathumbi, and J. Tyler for help with soil sampling; and J. Barkauskaite and M. Fidler for data analysis and reports preparation.

\section{LITERATURE CITED}

Abrams, M. M., and W. M. JarReLl. 1992. Bioavailability index for phosphorus using ion exchange resin-impregnated membranes. Soil Science Society of America Journal 56:1532-1537.

Allen, S. E., H. M. Grimshaw, J. A. Parkinson, and C. Quarmby. 1974. Chemical analysis of ecological materials. New York, NY: John Wiley and Sons. 565 p.

Arthington, J. D., F. M. Roka, J. J. Mullahey, S. W. Coleman, R. M. Muchovej, L. 0. LoLLIS, AND D. HITCHCOCK. 2007. Integrating ranch forage production, cattle performance and economics in ranch management systems for southern Florida. Rangeland Ecology and Management 60:12-18.

Beauchemin, S., R. R. Simard, and D. Cluis. 1996. Phosphorus sorption-desorption kinetics of soil under contrasting land uses. Journal of Environmental Quality 25:1317-1325.

Bennett, E. M., S. R. Carpenter, and N. F. Caraco. 2001. Human impact on erodable phosphorus and eutrophication: a global perspective. BioScience 51:227-234.

BLACKBURN, W. H. 1984. Impacts of grazing intensity and specialized grazing systems on watershed characteristics and responses, In: Developing strategies for rangeland management. National Research Council, National Academy of Sciences, Boulder, C0: Westview Press. p. 927-983.

Breeuwsma, A., J. G. A. ReiJerink, and O. F. Shoumans. 1995. Impact of manure on accumulation and leaching of phosphate in areas of intensive livestock farming. In: K. F. Steele (ED.). Animal waste and the land-water interface. New York, NY: Lewis Publishers-CRC Press. p 239-251.

Brooks, K. N., P. F. Ffolliott, H. M. Gregersen, and L. F. Debano. 1997. Hydrology and the Management of Watersheds. 2nd ed. Ames, IA: lowa State University Press. $502 p$.

Carpenter, S. R., N. F. Caraco, D. L. Correll, R. W. Howarth, A. N. Sharpley, and V. H. SмIтн. 1998. Nonpoint pollution of surface waters with $\mathrm{P}$ and nitrogen. Ecological Applications 8:559-568.

Cooperband, L. R., and T. J. Logan. 1994. Measuring in situ changes in labile soil phosphorus with anion exchange membranes. Soil Science Society of America Journal 58:105-114.

Cooperband, L. R., P. M. Gale, and N. B. Comerford. 1999. Refinement of the anion exchange membrane methods for soluble phosphorus measurement. Soil Science Society of America Journal 63:58-64.

Council for Agricultural Science and Technology (CAST). 2002. Environmental impacts of livestock on U.S. grazing lands. Council for Agricultural Science and Technology. Issue paper No. 22. 16 p.

D’Angelo, E., J. Crutchfield, and M. Vandiviere. 2001. Rapid, sensitive, microscale determination of phosphate in water and soil. Journal of Environmental Quality 30:2206-2209.

Edwards, D. R., T. K. Hutchens, R. W. Rhodes, B. T. Larson, and L. Dunn. 2000. Quality of runoff from plots with simulated grazing. Journal of the American Water Resources Association 36:1062-1073.

EMmerich, W. E., AND R. K. Heitschmidt. 2002. Drought and grazing: II. Effects on runoff water quality. Journal of Range Management 22:229-234.

Environmental Protection Agency (EPA). 1993. Methods for determination of inorganic substances in environmental samples. Report number EPA/600/R93-100. Environmental Monitoring Systems Lab, Cincinnati, OH. 178 p.

Florida Cattlemen's Association (FCA). 1999. Water quality best management practices for cow/calf operations in Florida. Kissimmee, FL: Florida Cattlemen's Association. $64 \mathrm{p}$.

Franzluebbers, A. J., J. A. Stuedemann, and H. H. Schomberg. 2000. Spatial distribution of soil carbon and nitrogen pools under grazed tall fescue. Soil Science Society of America Journal 64:635-639.

GoRnAK, S., AND J. Zhang. 1999. A summary of landowners surveys and water quality data from improved pasture sites in the northern Lake Okeechobee watershed. Applied Engineering in Agriculture 15:121-127.
HarwelL, M. A. 1998. Science and environmental decision making in South Florida. Ecological Applications 8:580-590.

Havens, K. E., AND C. Schelske. 2001. The importance of considering biological processes when setting total maximum daily loads (TMDL) for phosphorus in shallow lakes and reservoirs. Environmental Pollution 113:1-9.

Havens, K. E., V. J. Bierman Jr., E. G. Flaig, C. Hanlon, R. T. James, B. L. Jones, and V. H. Sмıтн. 1995. Historical trends in the Lake Okeechobee ecosystem. VI. Synthesis. Archiv fur Hydrobiologie Monographische Beitrage 107:99-109.

HaygaRTh, P. M., L. HePWORTh, and S. C. Jarvis. 1998. Forms of phosphorus transfer in hydrological pathways from soil under grazed grassland. European Journal of Soil Science 49:65-72.

HILL, L. R. 2003. Phosphorus in the soil profile of subtropical rangelands and associated wetlands [thesis]. Gainesville, FL: University of Florida. $81 \mathrm{p}$.

Hiscock, J. G., C. S. Thоurot, and J. Zhang. 2003. Phosphorus budget analysis relating to land use for the northern Lake Okeechobee watershed, Florida. Environmental Engineering 21:63-74.

James, R. T., V. H. Smith, And B. L. Jones. 1995. Historical trends in the Lake Okeechobee ecosystem. III. Water quality. Archiv für Hydrobiologie 107:49-69.

Kidder, G., C. G. Chambliss, and R. Mylavarapu. 2002. UF/IFAS standardized fertilization recommendations for agronomic crops. University of Florida, Florida Cooperative Extension Service, Fact Sheet SL-129. Gainesville, FL: University of Florida. Available at http://edis.ifas.ufl.edu/SS163. Accessed 21 November 2006.

KOKEMOR, J. 2004. The impact of cattle congregation on soil phosphorus content in grazed subtropical pastures in central Florida [thesis]. Bonn, Germany: University of Bonn. 79 pp. Available at http://www.archbold-station.org/abs/ maerc/maerccontrib.htm. Accessed 27 July 2006.

Line, D. E., W. A. Harman, and G. D. Jennings. 1998. Comparing sampling schemes for monitoring pollutant export from a dairy pasture. Journal of the American Water Resources Association 34:1265-1273.

Line, D. E., W. A. Harman, G. D. Jennings, E. J. Thompson, and D. L. Osmond. 2000. Non-point source pollutant load reductions associated with livestock exclusion. Journal of Environmental Quality 29:1882-1890.

Maezko, K. A., L. D. Bryant, D. W. Thompson, and S. J. Borchard. 2004. Putting the pieces together: assessing social, ecological, and economic rangeland sustainability. Rangelands 26:3-14.

Mapfumo, E., W. D. Willms, and D. S. Chanasyk. 2002. Water quality of surface runoff from grazed fescue grassland watersheds in Alberta. Water Quality Research Journal of Canada 37:543-562.

McDowell, R., A. Sharpley, P. Brookes, and P. Poulton. 2001a. Relationship between soil test phosphorus and phosphorus release to solution. Soil Science 166:137-149.

McDowell, R. W., J. J. Drewry, R. J. Paton, P. L. Carey, R. M. Monaghan, and L. M. Condron. 2003. Influence of soil treading on sediment and phosphorus losses in overland flow. Australian Journal of Soil Research 41:949-961.

McDowell, R. W., A. N. Sharpley, L. M. Condron, P. M. Haygarth, and P. C. Brooks. 2001b. Processes controlling soil phosphorus release to runoff and implications for agricultural management. Nutrient Cycling in Agroecosystems 59:269-284.

McSorley, R., AND G. W. TanNER. 2007. Effects of cattle stocking rates on nematode communities in south Florida. Rangeland Ecology and Management 60:31-35.

Mehlich, A. 1953. Determination of $\mathrm{P}, \mathrm{Ca}, \mathrm{Mg}, \mathrm{K}, \mathrm{Na}$, and $\mathrm{NH}_{4}$. Soil Testing Division, Pub. 1-53. Raleigh, NC: North Carolina Department of Agriculture. 8 p.

Mundy, G. N., K. J. NeXhip, N. R. Austin, And M. D. Collins. 2003. The influence of cutting and grazing on phosphorus and nitrogen in irrigation runoff from perennial pastures. Australian Journal of Soil Research 41:675-685.

Nair, V. D., D. A. Graetz, and K. R. Reddy. 1998. Dairy manure influences on phosphorus retention capacity of Spodosols. Journal of Environmental Quality 27:522-527.

Nash, D., M. Hannah, D. Halliwell, and C. Murdoch. 2000. Factors affecting phosphorus export from a pasture-based grazing system. Journal of Environmental Quality 29:1160-1166.

Olson, S. R., AND L. E. Sommers. 1982. Phosphorus. In: A. L. Page, R. H. Miller, and D. R. Keeney (EDS.). Methods of soil analysis. Part 2-Chemical and 
microbiological properties. Madison, WI: Soil Science Society of America, Inc. p 403-427.

RedDY, K. R. 1983. Soluble phosphorus release from organic soils. Agriculture Ecosystems and Environment 9:373-382.

Reddy, K. R., E. G. Flaig, and D. A. Graetz. 1996. Phosphorus storage capacity of uplands, wetlands and streams of the Lake Okeechobee watershed, Florida. Agriculture Ecosystems and Environment 59:203-216.

Reddy, K. R., And W. H. PatRick, JR. 1974. Effect of alternate aerobic and anaerobic conditions on redox potential, organic matter decomposition and nitrogen loss in a flooded soil. Soil Biology \& Biochemistry 7:87-94.

Schepers, J. S., And D. D. Francis. 1982. Chemical water quality of runoff from grazing land in Nebraska: I. Influence of grazing livestock. Journal of Environmental Quality 11:351-354.

Sharpley, A. N., S. C. Chapra, R. Wedepohl, J. T. Sims, T. C. Daniel, and K. R. Reddy. 1994. Managing agricultural phosphorus for protection of surface waters: issues and options. Journal of Environmental Quality 23:437-451.

Sharpley, A. N., M. J. Hedley, E. Sibbesen, A. Hillbricht, W. A. House, and L. Ryszkowski. 1995. Phosphorus transfers from terrestrial to aquatic ecosystems. In: H. Tiessen (ED.). Phosphorus and the global environment. Chichester, UK: John Wiley and Sons. p 171-199.

SPERRY, C. M. 2004. Soil phosphorus in isolated wetlands of subtropical bee cattle pastures [thesis]. Gainesville, FL: University of Florida. $65 \mathrm{p}$.

Sumner, S., W. Wade, J. Selph, J. Southwell, V. Hoge, P. Hogue, E. Jennings, P. Miller, and T. Seawright. 1992. Fertilization of established bahiagrass pasture in Florida. University of Florida Cooperative Extension Service, Circular 916. Gainesville, FL: University of Florida. Available at: http:// www.rcrec-ona.ifas.ufl.edu/cir916.html. Accessed 21 November 2006.

Swain, H. M., P. J. Bohlen, K. L. Campbell, L. O. Lollis, and A. D. Steinman. 2007. Integrated ecological and economic analysis of ranch management systems: an example from South Central Florida. Rangeland Ecology and Management $60: 1-11$.

Thurow, T. L. 1991. Hydrology and erosion. In R. K. Heitschmidt and J. W. Stuth (EDS.), Grazing management: an ecological perspective. Portland, OR: Timber Press. p 141-160.

Torbert, H. A., T. C. Daniel, J. L. Lemunyon, and R. M. Jones. 2002. Relationship of soil test phosphorus and sampling depth to runoff phosphorus in calcareous and noncalcareous soils. Journal of Environmental Quality 31:1380-1387.

Tremwel, T. K., K. L. Campbell, and L. W. Miller. 1996. Geometrically incremental volume sampling for ephemeral ditch pollutants. Applied Engineering in Agriculture 12:655-661.

USDA. 2003. National range and pasture handbook. Revision 1. Washington, DC: US Department of Agriculture, Natural Resource Conservation Service. 571 p. Available at: http://www.glti.nrcs.usda.gov/technical/publications/nrph.html. Accessed 21 November 2006.

Villapando, R. R., and D. A. Graetz. 2001. Water table effects on phosphorus reactivity and mobility in a dairy manure-impacted spodosol. Ecological Engineering 18:77-89.

West, C. P., A. P. Mallarino, W. F. Wedin, and D. B. Marx. 1989. Spatial variability of soil chemical properties in grazed pastures. Soil Science Society of America Journal 53:784-789.

Wood, M. K., AND W. H. BLACKBURN. 1981. Sediment production as influenced by livestock grazing in the Texas rolling plains. Journal of Range Management $34: 228-231$

Zielinski, R. A., W. H. Orem, K. P. Simmons, and P. J. Bohlen. 2006. Fertilizer-derived uranium and sulfur in rangeland soil and runoff; a case study in central Florida. Water, Air, \& Soil Pollution 176:163-183.

Zielinski, R. A., K. R. Simmons, And W. H. ORem. 2000. Use of ${ }^{234} \mathrm{U}$ and ${ }^{238} \mathrm{U}$ isotopes to identify fertilizer-derived uranium in the Florida Everglades. Applied Geochemistry 15:369-383. 